\title{
EXCESSIVE MENSTRUAL BLEEDING
}

RESEARCH UNIT REPORT NO. 5

73 Lower Baggot Street, Dublin 2. December 1991. 


\section{HRB EXCESSIVE MENSTRUAL BLEEDING RESEAR CH U N I T}

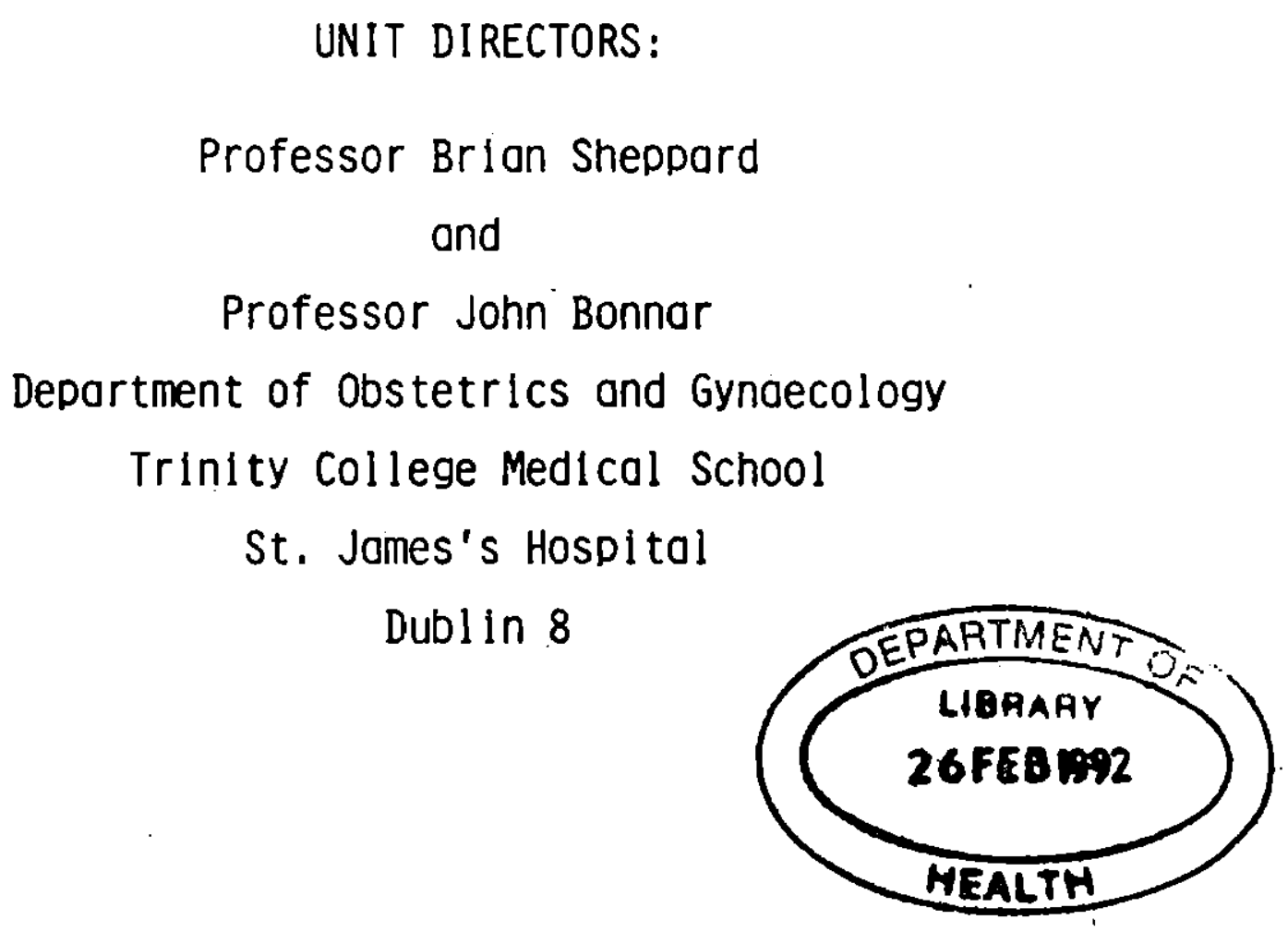




\section{HRB EXCESSIVB MENSTRUAL BLBEDING UNIT}

\section{SUMMARY OP MAIN PINDINGS}

One out of every 6 women have problems with heavy menstrual bleeding. This is a major cause of anaemia and poor health. often the condition is treated by hysterectomy. This Unit was established to investigate factors within the uterus (womb) which control the blood lost during menstruation. The aim is to reduce the need for treatment by hysterectomy.

Five hundred women, complaining of heavy menstrual bleeding, were recruited from Gynaecology Out-Patient Clinics. Laboratory measurement of their menstrual blood lost showed that excessive menstrual bleeding was present in $45^{\circ}$ of women; 558 having a loss which was within the normal range. The women's estimate and perception of the amount of menstrual loss does not tally with the actual amount of bleeding .

The study has shown that over 608 of women having hysterectomy for genuine excessive menstrual bleeding, have no detectable abnormality within their uterus. A detailed examination of biopsies of these uteri has revealed that a defective clotting mechanism coupled with an increase in the production of enzymes which stimulate the dilation of blood vessels are the major factors influencing the increased amount of blood loss from the uterus during menstruation. Medical treatment directed towards these factors has proved 
effective in restoring normal menstrual loss. The measurement of menstrual loss allows a more reliable management of excessive menstrual bleeding. This would greatly reduce the need for hysterectomy in women complaining of excessive menstrual bleeding. 


\section{EXCESSIVE MENSTRUAL BLEEDING RESEARCH UNIT}

DIRECTORS: Professor Brian L. Sheppard, MA.,M.SC.D.Phil.FRC.Path. Professor John Bonnar, MA., MD., FRCOG.

in collaboration with Dr S.C.Sharma, MA.,M.Sc.Ph.D. and assistance from Sr. E. Carroll, Nurse F. Buggy, Nurse M. Devitt, Nurse B. Hennelly, Dr. L. Daly Ph.D., Dr. M. Stack Ph.D., Ms. C. Boyle B.Sc., Ms. A. Connolly M.Sc., Ms. M. Jordan and Mr. E. McKone.

Trinity College Department of Obstetrics and Gynaecology and Department of Pharmacology and Therapeutics, Sir Patrick Dun Research Centre, st James's Hospital, Dublin.

Establishment Date: 1st September 1987.

Completion Date: 31st August 1991 (4 years). 
ORIGINAL OBJECTIVES OF THE STUDY

Excessive menstrual bleeding is a significant clinical and social problem for approximately 158 of all women during the reproductive years. In women of the age group $35-45$ years it is a major cause of impaired health and iron deficiency anaemia. The treatment is most often hysterectomy. Although menstruation has been studied for many years the mechanisms controlling menstrual blood loss from the uterus remain poorly understood.

The Unit was established to study the uterine mechanisms which are likely to be involved in the control of bleeding in women with normal and excessive menstrual bleeding. These are the structural and functional aspects of hamostasis including endometrial vasculature, blood coagulation and fibrinolysis, platelets, histamine, mast cells, prostaglandins and steroid receptors. The research study would provide a better understanding of the regulation of uterine bleeding and the causes of excessive menstrual bleeding. The longterm objectives are to gain a better treatment to control heavy bleeding and so reduce the need for hysterectomy. 
SUMMARY OF MAIN ACHIEVEMENTS

\title{
1. The diagnosis of excessive menstrual bleeding
}

\begin{abstract}
A total of 500 patients attending Gynaecology Out-Patient's clinics complaining of excessive menstrual bleeding were recruited into the study. objective measurement of menstrual blood loss over at least two cycles was performed in 416 of these women. 189 women (45\%) were found to have excessive menstrual bleeding with a loss greater than $80 \mathrm{ml}$ per menses (range $80-1059 \mathrm{ml}$ ); 227 women (55\%) were found to have normal menstrual blood loss $(1-77 \mathrm{ml})$. No correlation was found between the objective menstrual blood loss and the duration of menstrual bleeding, the number of sanitary towels used, haemoglobin levels, parity, age or the patient's perception of her menstrual loss. These findings indicate that objective measurement of menstrual blood loss is a vital diagnostic procedure in the evaluation and investigation of excessive menstrual bleeding.
\end{abstract}




\title{
DYSFUNCTIONAL UTERINE BLEEDING
}

\author{
500 PATIENTS
}

416 MEASURED MBL

\author{
227 (55 \%) MBL<80ml \\ (Range $1.0-77.0 \mathrm{ml}$ )
}

189 (45\%) MBL> $>80 \mathrm{ml}$

(Range $80-1,059 \mathrm{ml}$ )

HRB Study 


\section{PATIENTS INCLUDED IN STODY}

\begin{tabular}{|c|c|c|}
\hline & MBL $<80 \mathrm{ml}$ & MBL $>80 \mathrm{ml}$ \\
\hline \multirow[t]{2}{*}{ MBL } & $\bar{x} 39 \mathrm{ml}$ & $\bar{x} 182 \mathrm{ml}$ \\
\hline & Range $1-77 \mathrm{ml}$ & Range $80-1059 \mathrm{ml}$ \\
\hline \multirow[t]{2}{*}{ Haemoglobin } & $\bar{x} 12.9$ & $\bar{x} 12.0$ \\
\hline & Range $8.9-16.4$ & Range $7.2-14.8$ \\
\hline \multirow[t]{2}{*}{ Sanitary Towels } & $\bar{x} 17$ & $\vec{x} 25$ \\
\hline & Range $5-56$ & Range $9-60$ \\
\hline \multirow[t]{2}{*}{ Parity } & $\bar{x} 3.1$ & $\bar{x} 3.6$ \\
\hline & Range $0-8$ & Range $0-9$ \\
\hline \multirow[t]{2}{*}{ Age } & $\vec{x} 39$ & $\bar{x} 40$ \\
\hline & Range $30-50$ & Range $30-50$ \\
\hline
\end{tabular}




\section{MENGTRUAL BLOOD LOSS}

\section{Patient's Impression of Menstrual Blood Loss.}
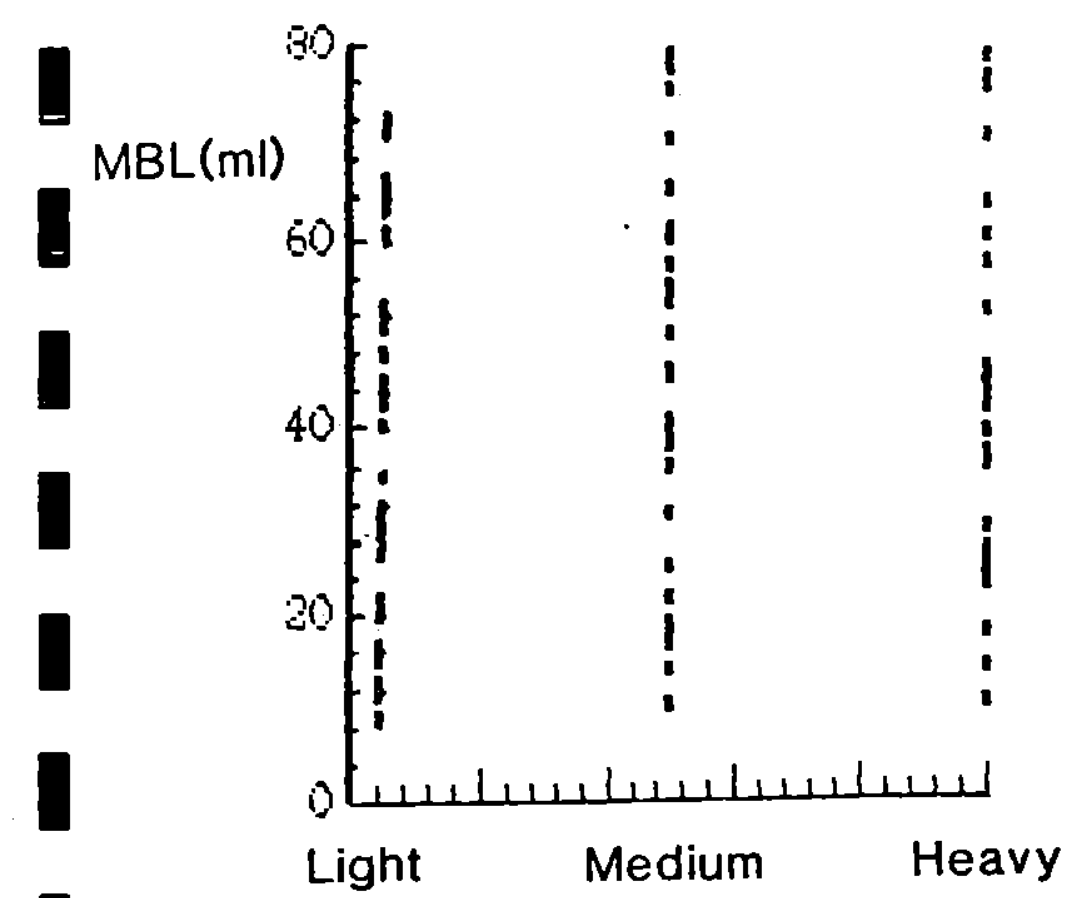

NORMAL

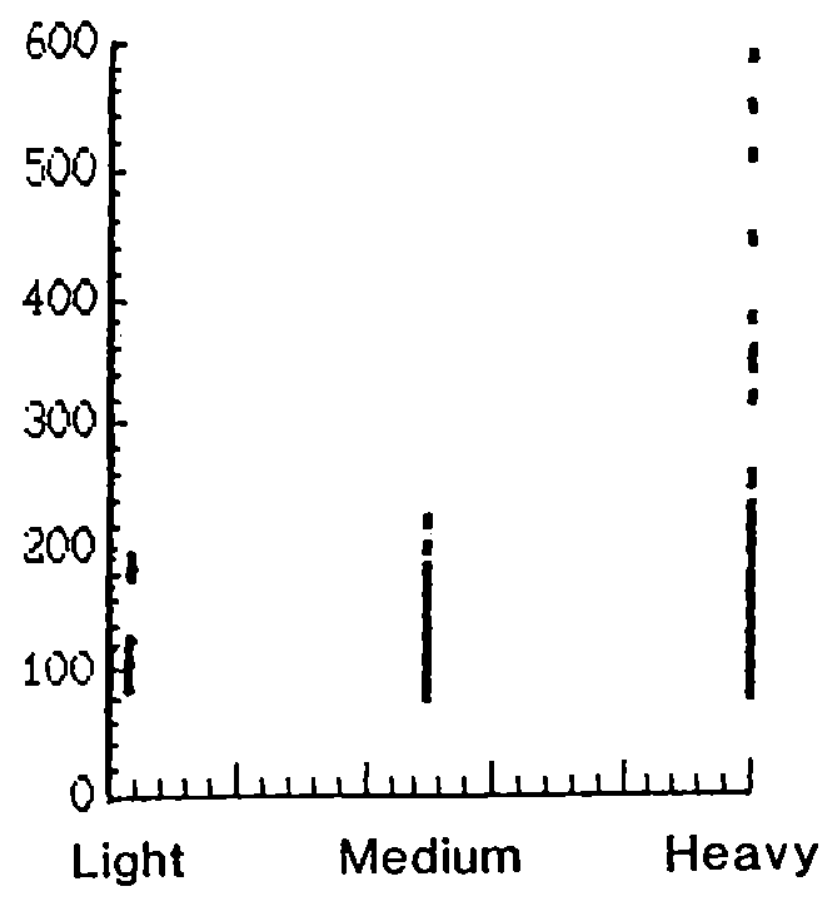

DUB 


\section{Endometrial Histology and Menstrual Bleeding}

140 of the recruited patients have undergone hysterectomy; 48 (358) had a normal menstrual blood loss and 92 (65\%) had a menstrual blood loss greater than $80 \mathrm{ml}$ per menses prior to hysterectomy. The hysterectomies covered the full range of the menstrual cycle and histological and biochemical analyses have been carried out on tissue biopsies from the uteri.

Histological examination of the uteri from the 92 patients with excessive menstrual bleeding showed 35 (38\%) to have minor pathology (focal adenomyosis, small fibroids, endometrial polyps or glandular hyperplasia). The remaining 57 (62\%) showed no uterine pathology and were classified as dysfunctional uterine bleeding (DUB). Only three uteri from the patients with DUB showed evidence of anovulation.

A computerised analysis of the volume to surface ratio of arteries, veins, capillaries and glands has been carried out on sections of endometrium. No significiant variation could be found in arterial, venous or capillary density during the menstrual cycle in women with normal menstrual loss or DUB and similarly no significant correlation could be found between vascular density and the endometrium and the degree of menstrual blood loss. These results indicate that excessive menstrual bleeding (DUB) is not due to increased numbers of vessels or glands in the uterine wall. 


\section{DYSFUNCTIONAL UTERINE BLEEDING}

HYSTERECTOMY

140 PATIENTS --.-- $48(35 \%) \mathrm{MBL}<80 \mathrm{ml}$

(Range 5-77ml)

-.-. $92(65 \%) \mathrm{MBL}>80 \mathrm{ml}$

(Range 80-1,056ml)

HRB STUDY/Dec.1991 


\title{
DYSFUNCTIONAL UTERINE BLEEDING
}

\author{
HYSTERECTOMY HISTOLOGY \\ 92 PATIENTS MBL $>80 \mathrm{ml}$ \\ $-57(62 \%)$ DUB \\ 3 Anovulation \\ $-35(38 \%)$ Pathology \\ 18 Foc. adenomyosis \\ 9 Small fibroids \\ 3 Endometrial polyps \\ 5 Gland. hyperplasia
}

HRB STUDY/Dec.1991 


\section{DYSFUNCTIONAL UTERINE BLEEDING}

\section{HYSTERECTOMIES(140)}

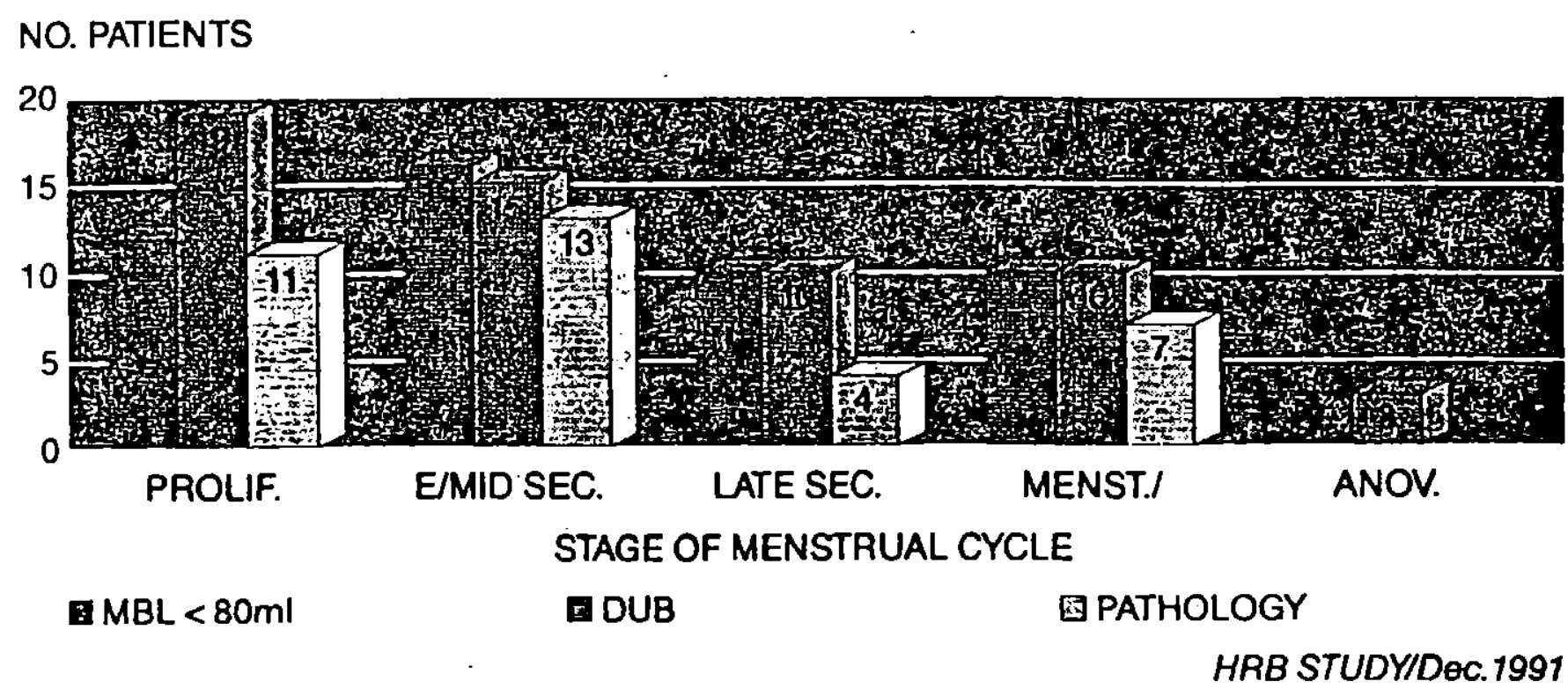




\section{Haemostatic platelet plug formation and menstrual bleeding}

Ultrastructural examination of haemostatic plug formation confirmed the important role of platelet and fibrin in endometrial haemostasis during the first 24 hours of menstruation. In the endometrium of patients with DUB a defective haemostasis was evident; whereas the haemostatic plugs were more common and present for a number of days in the endometrial blood vessels, the plugs ofteri consisted of poorly interdigitated, granulated platelets with a very minor fibrin component. This suggests that a diminished capacity of platelets to aggregate, coupled with a reduced fibrin deposition, during the process of menstruation in women with dysfunctional uterine bleeding renders the haemostatic plugs more fragile, allowing blood to flow more freely past dislodged thrombi. 


\section{Endometrial fibrinolysis and menstrual bleeding.}

The study has provided important new evidence on the role of increased local fibrinolysis in excessive menstrual bleeding. The activator of fibrinolysis, tissue plasminogen activator, has been localised by immuno-histochemistry in the endothelial cells of endometrial and myometrial blood vessels. Increased levels of tissue plasminogen activator have been found in endometrial extracts from uterine biopsies of women with dysfunctional uterine bleeding. A significant increase in tissue plasminogen activator, which correlates with the amount of menstrual bleeding, has been found in the endometrium of the late secretory phase, just prior to the onset of menstrual bleeding, in patients with dysfunctional bleeding ( $r=0.78 \mathrm{p}$ $0.02)$. These findings indicate that increased fibrinolysis plays a major role in the pathogenesis of dysfunctional uterine bleeding. 


\title{
DYSFUNCTIONAL UTERINE BLEEDING
}

\author{
UTERINE FIBRINOLYSIS \\ Endometrial Tissue Plasminogen Activator
}

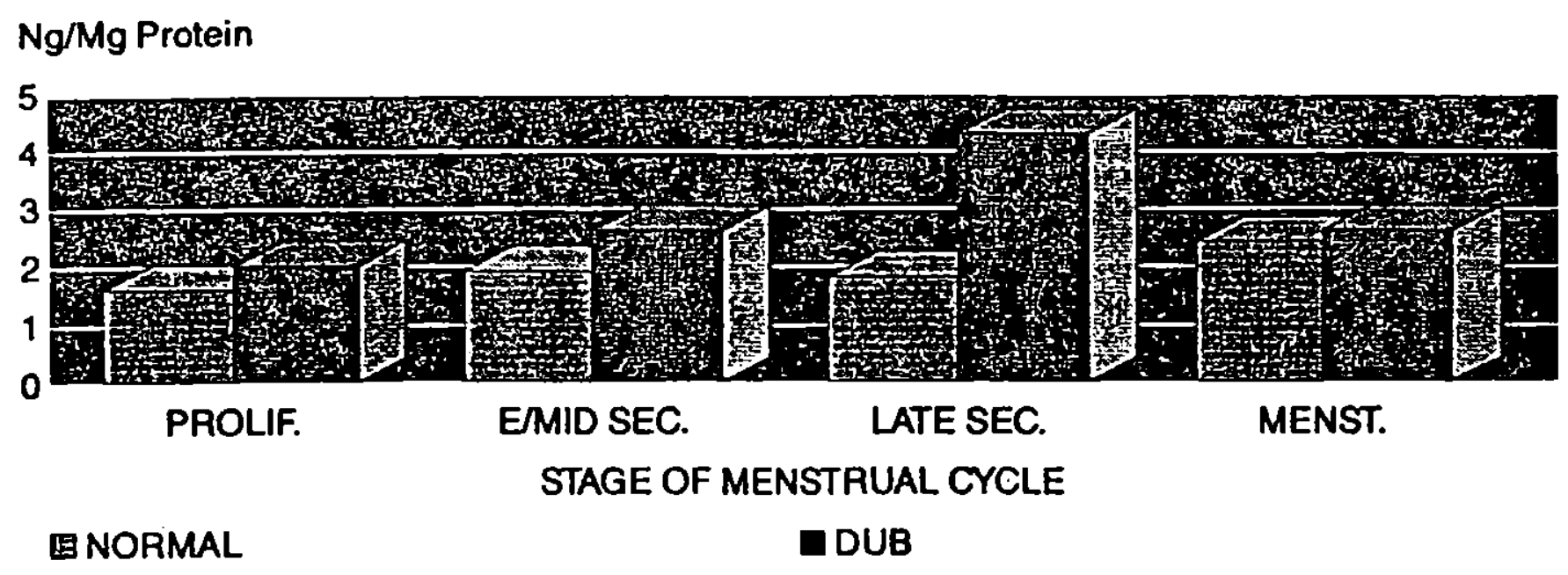

HRB STUDYIDOG. 1991 


\section{UTERINE PLASMINOGEN ACTIVATOR \\ Late Secretory Phase of Cycle MBL and Endometrial t-PAag}

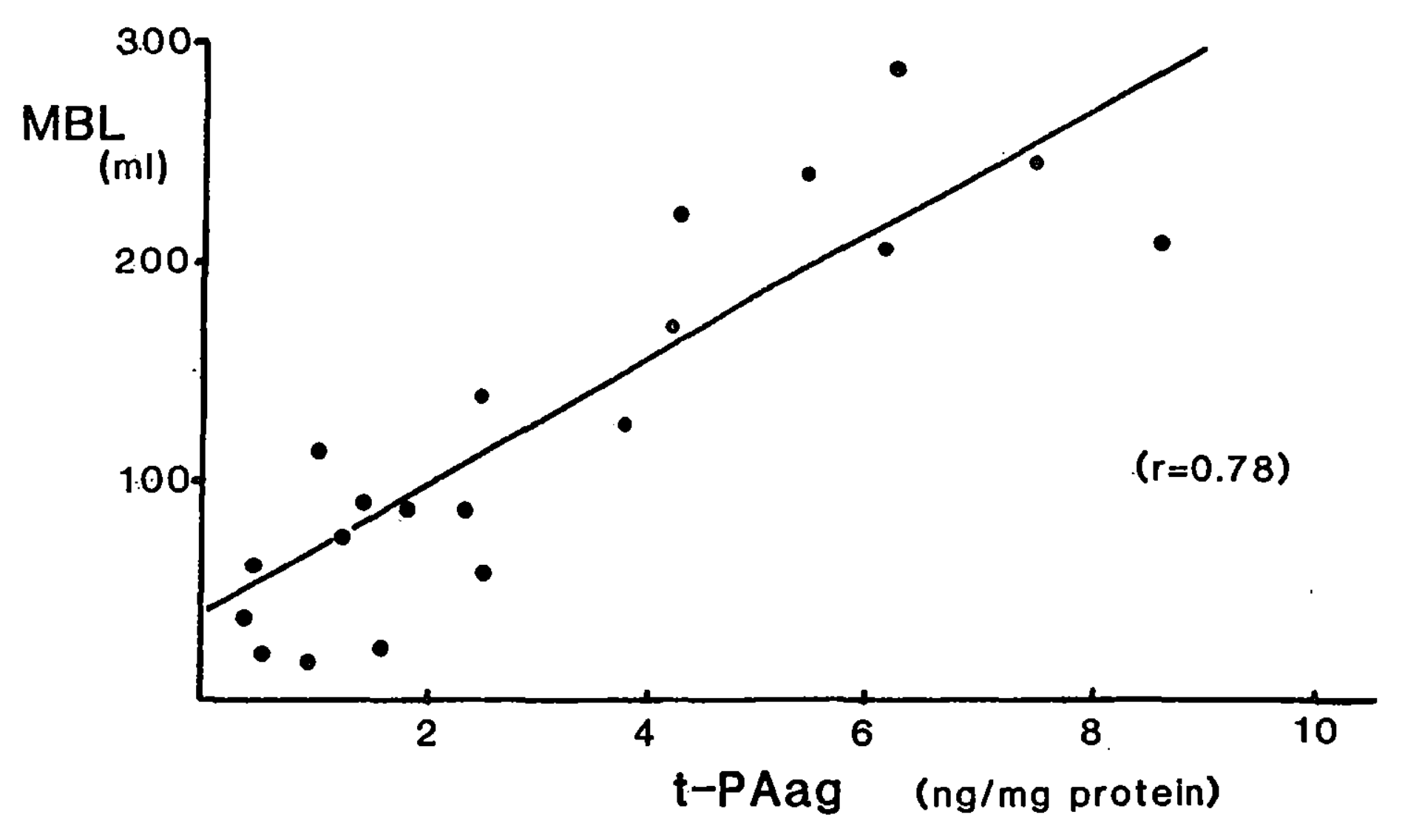




\section{Coagulation and Fibrinolysis in Menstrual Blood}

Examination of coagulation factors and the fibrinolytic enzyme system have shown menstrual blood collected during the first 48 hours of menstruation contains significantly higher levels of Factor $\underline{x} 1 \underline{1}$ than peripheral blood. Menstrual blood was found to contain no fibrinogen but very high levels of fibrin degradation products coupled with significantly low levels of antithrombin 111 and antiplasmin. Significantly high levels of tissue plasminogen activator were also detected in the menstrual fluid, again confirming the importance of increased fibrinolytic avtivity in the mechanism of excessive menstrual bleeding. 


\section{DYSFUNCTIONAL UTERINE BLEEDING}

\section{MENSTRUAL COAGULATION/FIBRINOLYSIS}

NG/ML

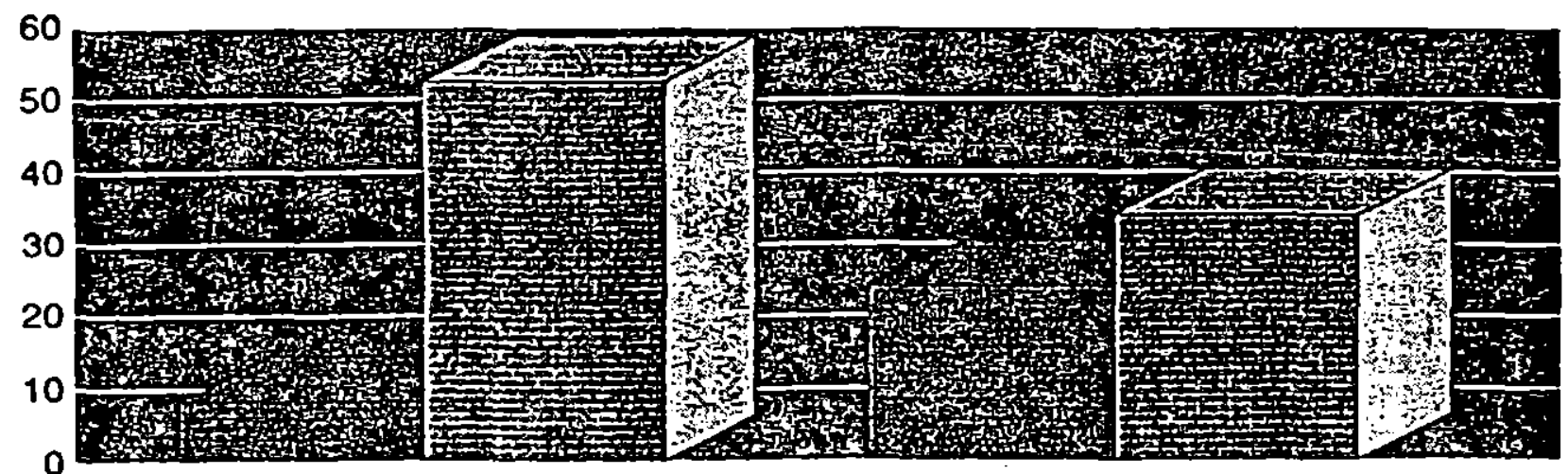

tPAag

PAl-1

D PERIPHERAL

Q MENSTRUAL 


\section{DYSFUNCTIONAL UTERINE BLEEDING}

\section{MENSTRUAL COAGULATION/FIBRINOLYSIS}

NG/ML

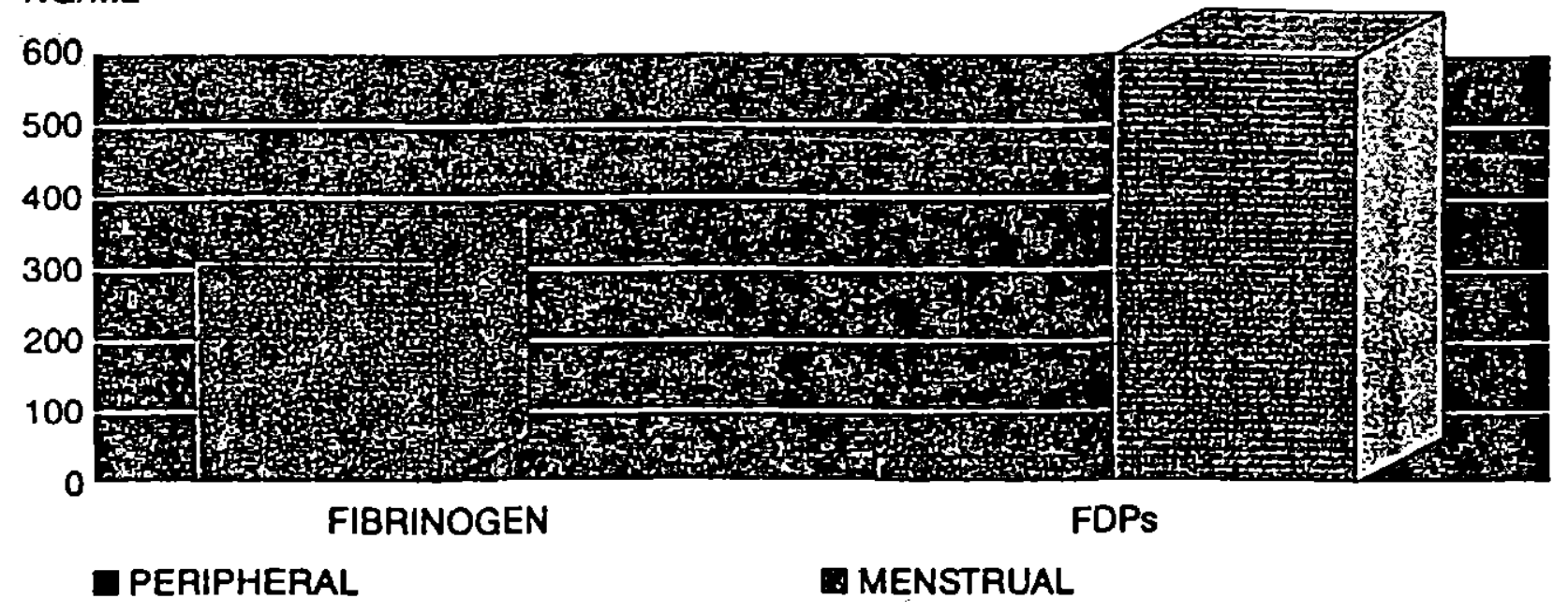

HRB STUDY 


\title{
DYSFUNCTIONAL UTERINE BLEEDING
}

\author{
MENSTRUAL COAGULATION/FIBRINOLYSIS
}

per cent

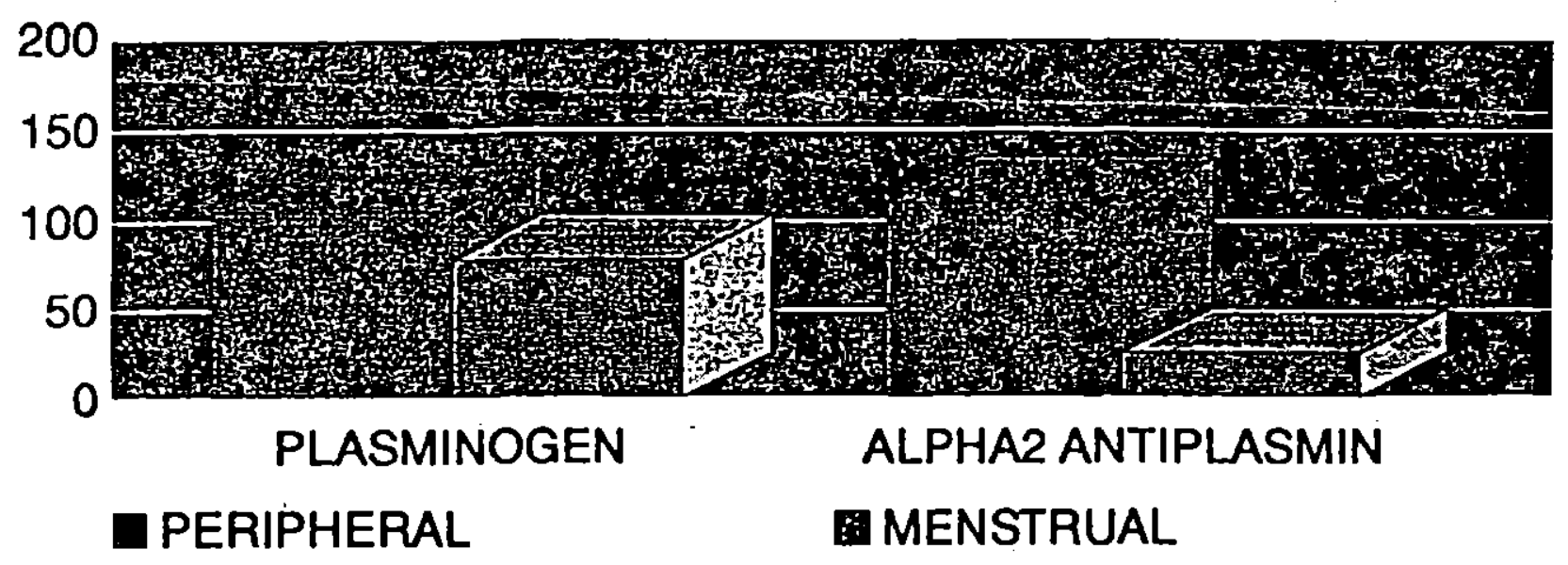

HRB STUDY 


\section{Endometrial Leukotrienes and Leukocytes}

Leukocyte concentrations and levels of leukotriene B4 were found to be higher in the endometrium of women with dysfunctional uterine bleeding than in women with normal menstrual loss. Whereas in the normal menstrual cycle, leukotriene B4 levels showed cyclical variation, in patients with DUB the levels remained high throughout the cycle. Leukotriene B4 is known to increase vascular permeability and release lysosomal enzymes and the increased levels in the endometrium of patients with dysfunctional uterine bleeding may be involved in increased glandular activity, stromal oedema and abnormal shedding of endometrium often observed in these patients. 


\section{Endometrial Prostaglandins and Menstrual Blood Loss}

The levels of vaso-dilator (measured as the metabolite PGEM and the metabolite of Prostacyclin, 6-keto PGF $\alpha$ ) and vaso-constrictor prostaglandins (measured as the metabolite PGFM and Thromboxane B2) in the endometrium were found to fluctuate throughout the menstrual cycle. A difference in the levels was also found between the patients with normal menstrual loss and those with dysfunctional uterine bleeding: this was particularly striking during the menstrual phase of the cycle where in patients with dysfunctional uterine bleeding the levels of PGEM and 6-keto PGF $1 \propto$ were higher and the levels of PGFM and Thrombozane B2 were lower than in patients with normal menstrual loss. This indicates that dysfunctional uterine bleeding is associated with a shift towards the production of high levels of vaso-dilatory prostaglandins and away from prostaglandins that stimulate vaso-constriction and platelet aggregation. 


\section{DYSFUNCTIONAL UTERINE BLEEDING}

\section{PROSTAGLANDINS IN MENSTRUAL ENDOMETRIUM}

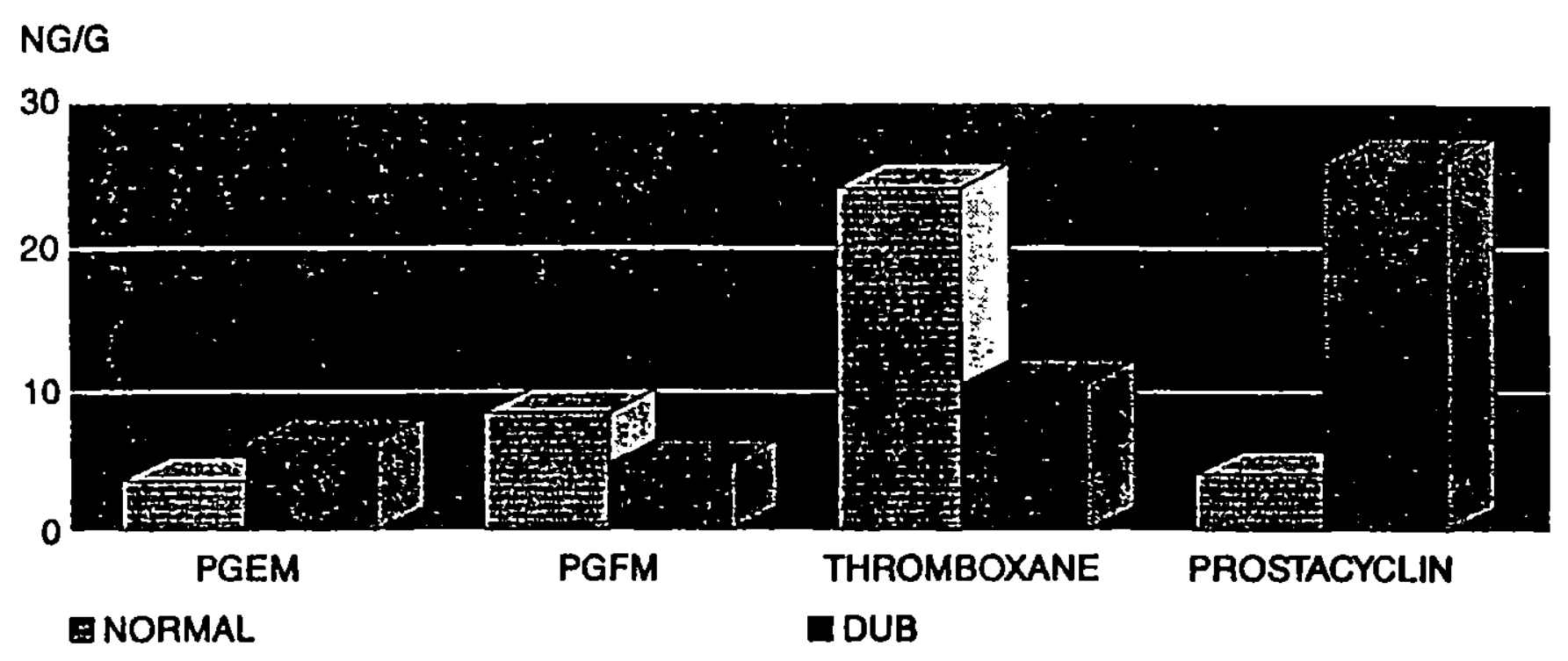

HRB STUDYDOC.1991 


\section{Mast Cells and Histamine in the Uterine Wall}

Mast cells, identified by staining of metachromatic granules within the cell cytoplasm, were. found to be unevenly distributed throughout the uterine wall. No distinct pattern in mast cell distribution in relation to the menstrual cycle or degree of menstrual bleeding has emerged; more degranulation of the mast cells was apparent in the pre-menstrual phase of the cycle. Similarly, no distinct pattern emerged in the levels of histamine, which is secreted by mast cells, throughout the menstrual cycle in either normal menstruation or in dysfunctional uterine bleeding. We conclude that histamine and mast cells may be involved in the physiological process of menstruation but do not appear to play a major part in the aetiology of dysfunctional uterine bleeding. 


\section{Oestrogen and Progesterone Receptors in the Uterine wall}

Ninty-five per cent of the patients who had hysterectomy for dysfunctional uterine bleeding had ovulatory cycles and circulating peripheral hormone levels within the normal range at the time of hysterectomy. However, immuno-cytochemical staining has shown a variation in oestrogen and progesterone receptor levels in uterine endometrium and myometrium through the menstrual cycle which is significantly different between women with normal menstrual loss and patients with dysfunctional uterine bleeding. Whereas oestrogen receptor levels were significantly lower in the late secretory phase, progesterone receptor staining levels were significantly higher in patients with dysfunctional uterine bleeding than in patients with normal menstrual loss. These results may be of particular importance as oestrogen and progesterone are both known to influence fibrinolytic activity within the uterus. 
CONCLUSION

This study has shown conclusively that when a woman complains of excessive menstrual bleeding the clinical diagnosis is likely to be erroneous in at least $55 \%$ of women. The women's estimate and perception of the amount of menstrual loss shows no correlation with the actual amount of bleeding. Objective measurement of the menstrual loss would provide an accurate diagnosis of excessive menstrual bleeding. This would allow patients who have a normal loss to be reassured and unnecessary treatment and surgery avoided. In those with true menorrhagia medical treatment can be assessed before a decision on the need for hysterectomy. These measures would reduce by at least $50 \%$ the number of hysterectomies being carried out.in women complaining of excessive menstrual bleeding.

The results of this study suggest that genuine excessive uterine bleeding is due to local endometrial or myometrial dysfunction. Impaired haemostasis, coupled with increased uterine fibrinolysis and an imbalance of prostaglandin production, have been shown to be the major factors involved in the mechanism of dysfunctional uterine bleeding. This provides clear scientific evidence for treatment of dysfunctional uterine bleeding with fibrinolytic inhibitors and prostaglandin synthetase inhibitors. 
OTHER PROJECTS ARISING IN THE COURSE OF THE MAIN RESEARCH OBJECTIVE

We are currently carrying out a randomised study of medical treatment taken during menstruation for dysfunctional uterine bleeding. The results to date show that menstrual blood loss is reduced by $30 \%$ in patients taking the prostaglandin synthetase inhibitor, Mefenamic Acid, and by nearly $60 \%$ in patients taking the fibrinolytic inhibitor, Tranexamic Acid. Ethamsylate, a treatment which is widely used for excessive menstrual bleeding was found to have no significant effect. our recent finding of increased levels of tissue plasminogen activator in the late secretory endometrium in patients with dysfunctional uterine bleeding indicate that a reduction in menstrual bleeding may be more effective if the fibrinolytic inhibitor was administered 2-3 days prior to the onset of bleeding. We are designing a study to examine the possible benefits of this form of medical therapy of dysfunctional uterine bleeding. 


\section{MEFENAMIC ACID MENSTRUAL BLOOD LOSS}

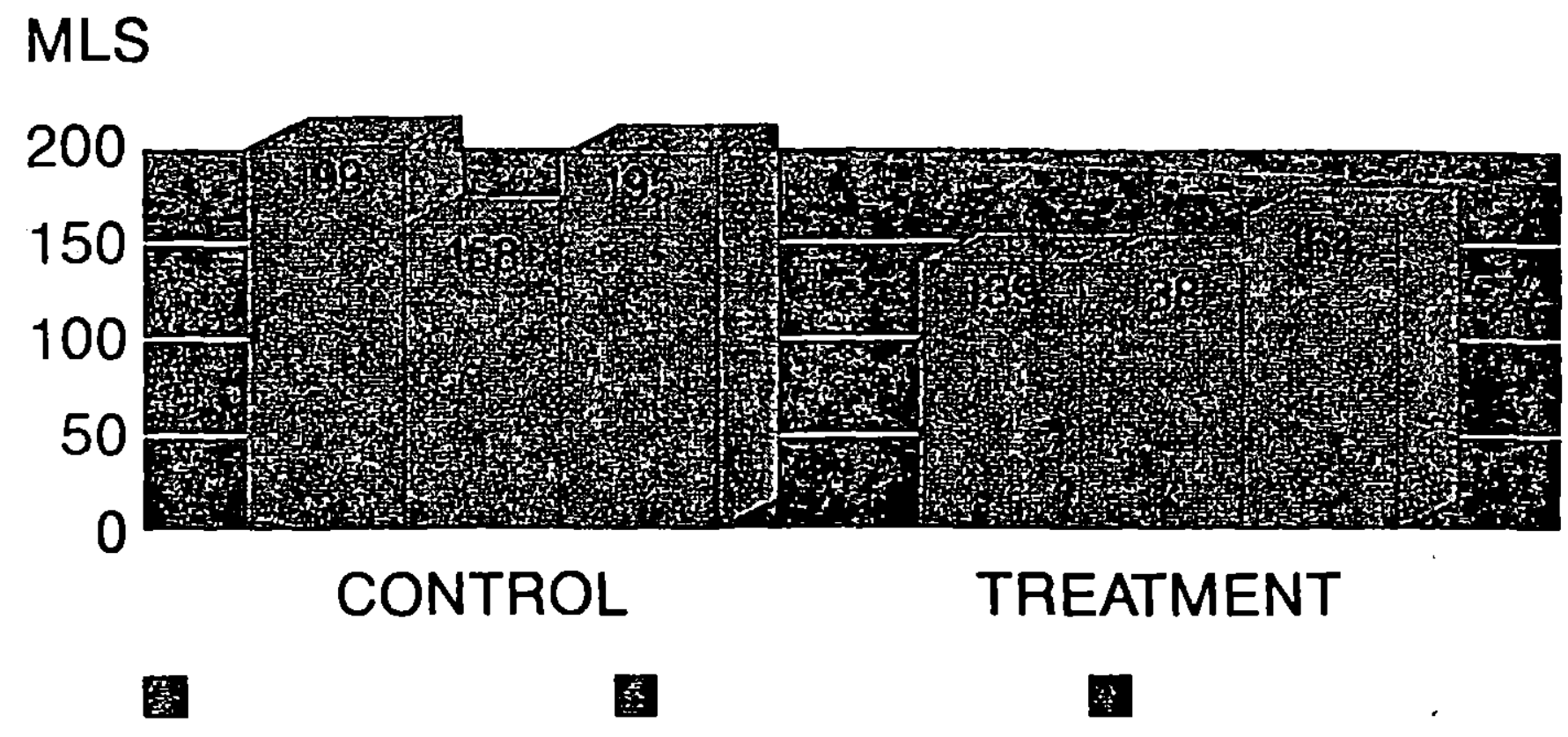




\section{TRANEXAMIC ACID MENSTRUAL BLOOD LOSS}

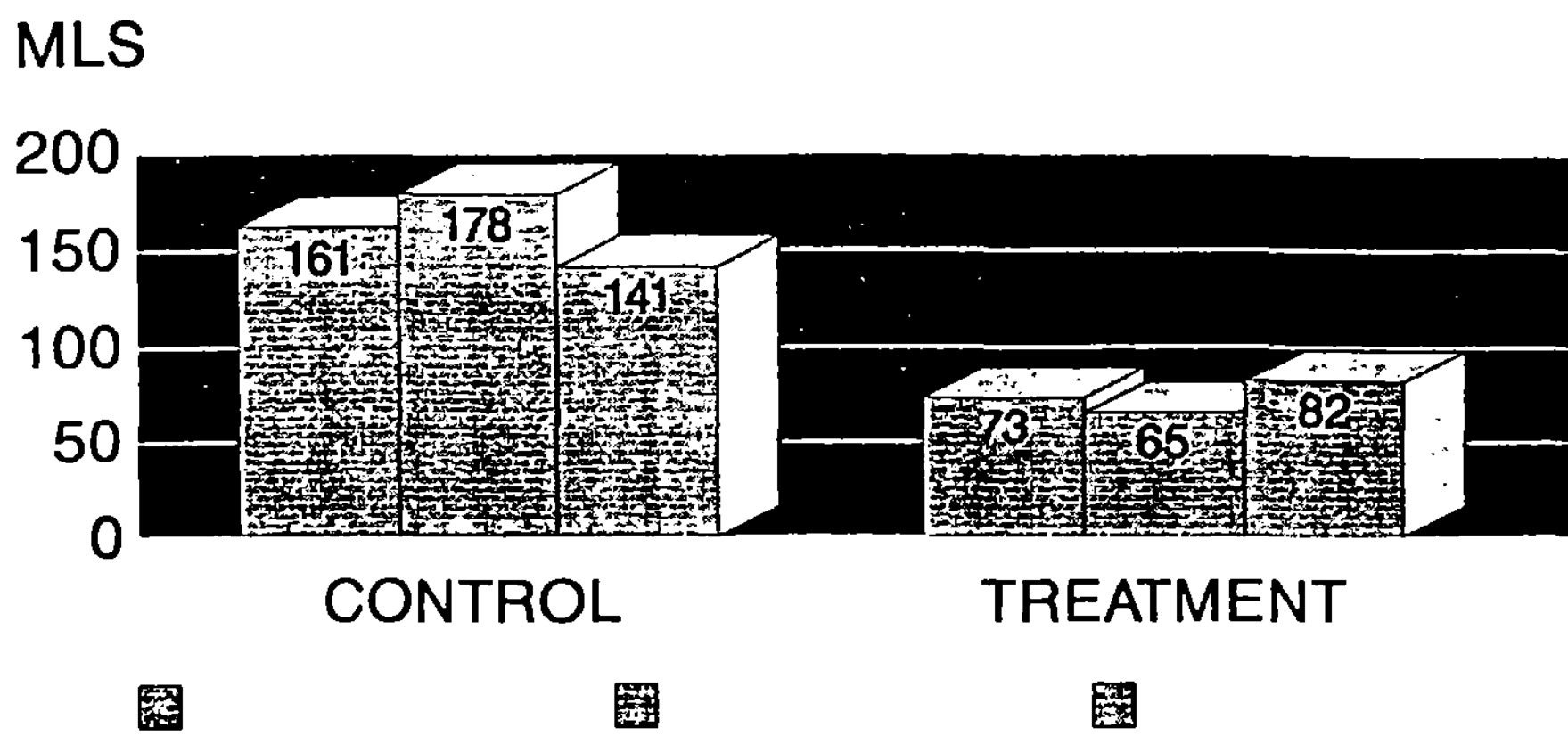




\section{MENSTRUAL BLOOD LOSS CONTROL AND TREATMENT CYCLES}

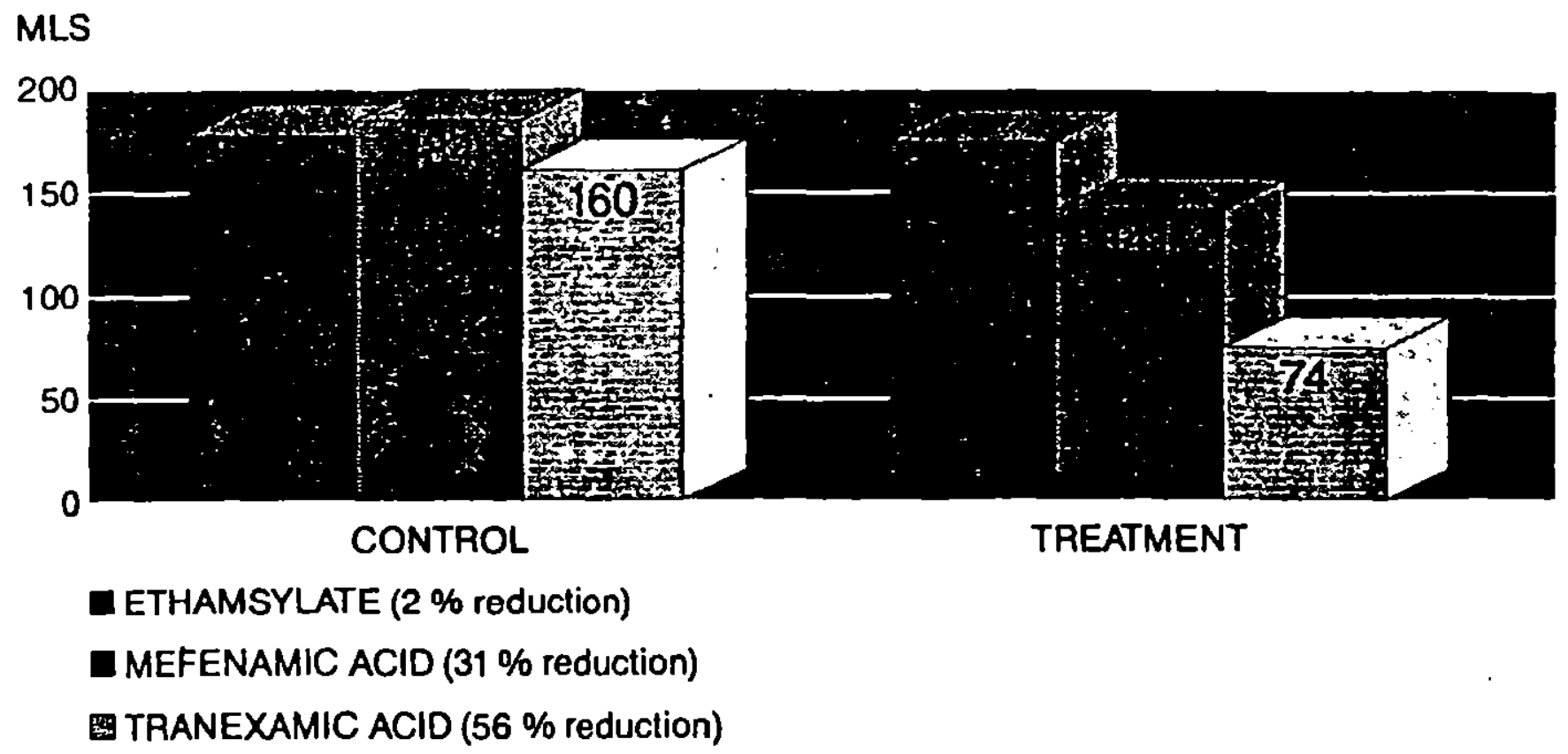


Jordan, M., Sheppard, B.L. and Bonnar, J. Immunocytochemistry of oestrogen and progesterone receptors in the uterus of women with normal and excessive menstrual bleeding. Irish $\mathrm{J}$. Med. Sci. 159, 151-152 (1990).

Sharma, S.C., Sheppard, B.L. and Bonnar, J. Endometrial tissue levels of $\mathrm{PGE}_{2}$ and $\mathrm{PFG}_{2}$ metabolites in women with normal menstruation and dysfunctional uterine bleeding. Irish J. Med. Sci. 159, 152 (1990).

Sheppard, B.L. Coagulation and electron microscopy studies in menorrhagia. In: Reproductive Endocrine Disorders - Vol 2 : Dysfunctional uterine bleeding. Ed. R.W. Shaw. Parthenon Publishing pp 25-42. 1990.

Sharma, S.C., Sheppard, B.L. and Bonnar, J. Endometrial leukotriene B4 and leukocyte concentrations in women with normal menstruation and dysfunctional uterine bleeding. Irish J. Med. Sci. In press.

Mckone, E., Sheppard, B.L. and Bonnar, J. Uterine histology and menstrual blood loss. Irish J. Med. Sci. In press.

Sheppard, B.L. The pathophysiology of dysfunctional uterine bleeding. In: Advances in Gynaecological Pathology. Eds. D. Lowe and H. Fox. Churchill Livingstone. In press. 
Sharma S.C., Sheppard, B.L. and Bonnar J. Menstrual and peripheral levels of 6 -keto-PGF 1 and $\mathrm{TXB}_{2}$ in dysfunctional uterine bleeding. Irish J. Med. Sci. In press.

Sheppard, B.L., Buggy, F. and Bonnar, J. The perception of excessive menstrual bleeding. Irish J. Med. Sci. In press.

Bonnar, J. and Sheppard, B.L. Dysfunctional uterine bleeding: who needs hysterectomy? Forty-First Annual Meeting of the Society of Pelvic Surgeons. 36 (1991). 